\title{
Review
}

\section{Programmed cell death during plant growth and development}

\author{
Eric P. Beers \\ Department of Horticulture, Virginia Polytechnic Institute and State University, \\ Blacksburg, Virginia 24061-0327, USA
}

Received 24.2.97; revised 30.6.97; accepted 14.7.97

Edited by B.A. Osborne

\begin{abstract}
This review describes programmed cell death as it signifies the terminal differentiation of cells in anthers, xylem, the suspensor and senescing leaves and petals. Also described are cell suicide programs initiated by stress (e.g., hypoxiainduced aerenchyma formation) and those that depend on communication between neighboring cells, as observed for incompatible pollen tubes, the suspensor and synergids in some species. Although certain elements of apoptosis are detectable during some plant programmed cell death processes, the participation of autolytic and perhaps autophagic mechanisms of cell killing during aerenchyma formation, tracheary element differentiation, suspensor degeneration and senescence support the conclusion that nonapoptotic programmed cell death pathways are essential to normal plant growth and development. Heterophagic elimination of dead cells, a prominent feature of animal apoptosis, is not evident in plants. Rather autolysis and autophagy appear to govern the elimination of cells during plant cell suicide.
\end{abstract}

Keywords: programmed cell death, plants, apoptosis, protease

Abbreviations: pcd, programmed cell death; GA, gibberellic acid; PARP, poly(ADP-ribose) polymerase

\section{Introduction}

In plants, as in animals, programmed cell death (pcd) results when cell suicide pathways are activated as part of normal growth and development. Cell suicide pathways may also be activated in response to certain biotic and abiotic external factors. In animals, the ultrastructural changes occurring during apoptosis, a particular type of pcd, allow pcd to be distinguished from necrosis. Necrosis results from severe injury and does not appear to rely on cell suicide programs. This review examines pcd during sex determination, anther dehiscence, pollen tube growth, fertilization, embryo suspensor growth, seed germination, aerenchyma formation, tracheary element and sclereid differentiation, sieve element differentiation, and leaf and flower petal senescence. Due to the broad range of topics covered, it was not possible to present in this space comprehensive reviews of each subject. Rather, to examine whether apoptosis is a universal pathway to pcd in plants, I have reviewed reports describing morphology of cells undergoing pcd during the processes listed above. Information concerning potential biochemical and molecular markers for plant pcd is also reviewed, with special attention to possible roles for proteases, since research in this area has established proteases as important mediators of pcd in animals.

There is continuing interest in whether apoptosis occurs in plants. Electron microscopy has revealed that during apoptosis in animals, chromatin condenses and segregates into sharply delineated masses positioned at the nuclear envelope (Ellis et al, 1991; Kerr and Harmon, 1991). Condensed chromatin is electron dense and is often described as pycnotic. The cytoplasm also condenses and both the nuclear and cellular outlines appear lobed. Over the next few minutes, nuclear fragmentation occurs and deeply lobed convolutions of the cell surface are evident. The protruding lobes then separate and produce membranebound apoptotic bodies containing intact organelles. Apoptotic bodies are phagocytosed by adjacent cells. At the biochemical level, apoptosis results in fragmentation of nuclear DNA, probably catalyzed by a calcium-dependent nuclease (Wyllie et al, 1980), yielding a ladder of DNA on agarose gels (Wyllie, 1980). Based on the above characteristics, it appears that apoptosis occurs in mycotoxin-treated plant protoplasts (see Gilchrist, 1997, this issue) and during plant pathogen-induced cell death (Ryerson and Heath, 1996; and see Morel and Dangl, 1997, this issue). It is concluded, however, that apoptosis is not a universal pathway to plant pcd, and that instead, many plant cell suicide programs depend on autophagic and autolytic mechanisms for cell killing. Plant cell death was recently reviewed by Greenberg (1996) and Jones and Dangl (1996) and other relevant reviews are indicated below.

\section{Death during plant reproduction}

The events that comprise plant sexual reproduction have been examined at the genetic, physiological, ultrastructural, biochemical, and molecular levels. From these studies have emerged examples of pcd as a necessary component of sex determination, gamete development, fertilization and embryogenesis. There is increasing interest in the possible utility of model systems developed for the study of plant reproduction as model systems for the study of plant pcd. In this regard, characterization of sex determination mutants and embryodefective mutants as well as in vitro experiments with isolated 
embryo sacs may soon begin to identify the components of plant pcd pathways.

\section{Sex determination}

Although most flowering plants bear flowers that contain both male and female sex organs (perfect flowers), unisexuality in asparagus (Bracale et al, 1991), maize (DeLong et al, 1993) and white campion (Grant et al, 1994), results from the programmed death of preformed sex organs (recently reviewed by Dellaporta and Calderon-Urrea, 1993). In maize, pcd in both male and female sex organs is characterized by increased vacuolation and loss of organelles (Cheng et al, 1983). Outwardly, cells of degenerating organs in maize and white campion (Grant et al, 1994) appear sunken, indicating that tonoplast rupture may be a final event in the sex organ abortion process. Vascular development in asparagus is incomplete in female organs of male flowers and in male organs of female flowers (Bracale et al, 1991). Whether the lack of vascular development promotes cell death in these organs via the withholding of phytohormones or other signaling molecules, or represents a secondary effect of cell death is not known. The presence of mature vascular tissue in the degraded stamen rudiment in female flowers of white campion (Grant et al, 1994), however, argues against vascular discontinuity as a necessary inducer of cell death.

The characterization of two recently cloned genes necessary for female sex organ abortion, Ts2 (DeLong et al, 1993) and Gsf1 (Li et al, 1997), of maize and Tripsacum, respectively, may eventually reveal the biochemistry responsible for the effects of exogenously applied feminizing phytohormones, such as GA (Hansen et al, 1976). The predicted product of these genes is similar to hydroxysteroid dehydrogenases, and may catalyze conversion of a GA-like precursor to a pcd promoter that acts either indirectly by regulating as yet unidentified genes, or directly as a cytotoxic molecule (DeLong et al, 1993).

\section{Anther dehiscence}

The dehiscence program that leads to the rupture of anthers and release of pollen represents a dramatic example of the coordinated death of several different cell types in a single organ (reviewed by Goldberg et al, 1993) and is associated with increased expression of a cysteine protease (Koltunow et al, 1990). Anther rupture occurs at the stomium after degeneration of the tissue located between the stomium and the connective tissue of the pollen sacs. In addition to death of the cluster of cells directly beneath the stomium, protoplast degeneration is the fate of four other cell types in tomato anthers: the tapetum, epidermal cells adjacent to the stomium, the endothecium and the connective (Bonner and Dickinson, 1989). Some evidence for the involvement of hydrolytic enzymes in anther pcd has been presented. Cellulase protein level increases as anthers mature (del Campillo and Lewis, 1992). The TA56 thiol proteinase mRNA accumulates within the circular cluster of cells between the stomium and the connective (Koltunow et al, 1990). This is paralleled by an increase in ubiquitin and/or ubiquitinated protein levels in the same tissue (Li et al, 1995). Following degeneration of the circular cluster of cells, TA56 mRNA increases in both the stomium and connective (Koltunow et al, 1990). Hence proteolytic pathways involving both thiol proteases and perhaps ubiquitin conjugation appear to be active just before degeneration of specific cell types in anthers, suggesting a role for multiple proteolytic systems during anther cell death. The ubiquitin-dependent pathway of proteolysis is induced during pcd in degenerating insect muscles (Haas et al, 1995).

\section{Death of incompatible pollen}

Pollen released from the anther as a result of the dehiscence program will hydrate and germinate producing a pollen tube when it arrives on the epidermis of the cells of the stigma; but in some cases, death of the pollen tube may soon follow. The stigma is connected to the ovary by the transmitting tissue that passes through the style (Esau, 1965). The transmitting tissue facilitates the growth of the pollen tube through the style. One of the roles of the stigma and style is to discriminate between appropriate and inappropriate pollen grains, resulting in the prevention of the growth of interspecific and in some cases intraspecific pollen. The prevention of self-pollination, a condition known as self-incompatibility has evolved presumably to prevent the deleterious effects of inbreeding (recently reviewed by Newbigin et al, 1993; Nasrallah et al, 1994; Dodds et al, 1996). Both sporophytic (determined by the diploid genotype of the parent plant) and gametophytic (determined by the haploid genotype of the pollen grain) mechanisms have been described for the control of the selfincompatibility phenotype.

Self-incompatibility in members of the Solanaceae (potato and tobacco), Rosaceae (roses and many tree fruits) and Scrophulariaceae (snapdragon) is of the gametophytic type and is controlled by a highly polymorphic locus called the S-locus. In the Solanaceae, when a pollen tube is growing through a style that has the same S-alleles as the pollen tube, its growth rate slows and death soon follows. The genes known to be encoded by the Slocus in the Solanaceae are an allelic series of stylar ribonucleases known as S-RNases, and activity of SRNases as allele-specific cytotoxins is thought to be essential for the expression of self-incompatibility (Dodds et al, 1996). In vitro assays indicate that S-RNases nonspecifically degrade RNA (McClure et al, 1990). In vivo, however, during growth in Nicotiana alata styles, only the rRNA of incompatible and not that of compatible pollen tubes is degraded. Two models have been proposed to explain how stylar S-RNase gains specific access to RNA of incompatible pollen (Dodds et al, 1996; McCubbin et al, 1997). In the first model, S-RNases are excluded from the pollen tube but the S-locus product in pollen recognizes the corresponding S-RNase present in the extracellular matrix of the stylar transmitting tissue and allows it to enter the incompatible pollen tube. The second model proposes that S-RNase enters all pollen tubes but is inactivated or sequestered from the substrate in compatible pollen tubes. The S-locus product in incompatible pollen tubes would, in this model, prevent its corresponding S-RNase from being inactivated or sequestered. The end result 
according to either model would be the non-autonomous inhibition of protein synthesis leading to the observed arrest of cell growth (Herrero and Dickinson, 1981), and ultimately to death. Although RNase activity is one of several hydrolytic markers for autolysis during tracheary element differentiation (Ye and Droste, 1996) and for leaf (Taylor et al, 1993) and petal (Matile and Winkenbach, 1971) senescence, stylar S-RNase appears to be the sole lytic agent necessary (Dodds et al, 1996, and references therein) for a process that may be initiated by the action of a single cell death promoter - the as yet unidentified pollen S-locus product.

\section{Degeneration of haploid megaspores}

Upon arrival at the ovary, pollen tubes must enter the embryo sac for successful fertilization. In the majority of angiosperms the single embryo sac develops from a surviving haploid megaspore: three of the four megaspores formed by meiosis having degenerated. In the fern Marsilea, megaspore death involves chromatin pycnosis (Bell, 1996). The presence of pycnotic chromatin led Bell (1996) to propose that Marsilea megaspore death was apoptotic. Chromatin pycnosis is a morphological marker for both apoptotic and nonapoptotic pcd (Schwartz, 1992). Pycnotic chromatin in apoptotic nuclei is typically appressed to the inner surface of the nuclear membrane in large electron dense masses with sharply delineated margins. In contrast, pycnotic chromatin in nonapoptotic nuclei may be present throughout the nucleus as smaller electron dense bodies with diffuse edges. The above distinction between the morphologies of pycnotic chromatin in nuclei of apoptotic versus nonapoptotic dying cells (Schwartz, 1992) indicates that reports of pycnotic nuclei not accompanied by further descriptions of chromatin as well as other aspects of nuclear morphology are probably insufficient for determining pcd type. With regard to megaspore death in angiosperms, investigations of events at the ultrastructural, biochemical and molecular levels may reveal new details of pcd in economically important seed plants.

\section{Death of synergids}

Programmed cell death also occurs within the embryo sac during fertilization. Usually the pollen tube enters the ovule through the micropyle, a narrow opening in the ovular tissue. Located at the micropylar pole of the embryo sac are the egg cell and usually two synergids, although synergids are absent from some species (Willemse and Van Went, 1984). The pollen tube penetrates one of the synergids, which then degenerates (Willemse and Van Went, 1984). It is possible that synergid degeneration after pollen tube penetration is a necrotic response to injury. However, that synergid degeneration may also occur in the absence of pollination (recently reviewed by Russell and Dumas, 1992), indicates that, at least in some species, synergids are programmed for death (Van Went and Cresti, 1988; Sumner, 1992). Once inside the synergid, pollen tube growth ceases and an opening forms in the tube wall (Willemse and Van Went, 1984), through which the pollen tube cytoplasm and two sperm cells are discharged. One sperm cell is transferred to the egg for zygote formation and the other is transferred to the central cell for endosperm formation.

Synergid death has been extensively characterized in tobacco, pearl millet and cotton. Degeneration of the synergid membranes nearest the micropylar region is detectable when the pollen tube tip arrives at the receptive synergid in Nicotiana tabacum (Huang and Russell, 1994), implying that in this species initiation of the synergid death program may depend on signals from the pollen tube. Complete degeneration, however, does not occur until after penetration by the pollen tube when the synergid vacuole collapses and the pollen tube releases its contents into the synergid. Ultimately, even plasma membrane integrity is lost (Russell and Dumas, 1992). At this point cytoplasm may leak from the degenerated synergid and pass between other cells of the embryo sac. Culturing unfertilized cotton ovules in the presence of the phytohormones GA and IAA promotes synergid degeneration, with an increase in cytoplasmic density and vacuolar collapse representing early events in synergid death (Jensen et al, 1997). The roles of phytohormones in synergid degeneration in planta are not known.

Several reports have described dynamic changes in calcium distribution prior to and during synergid degeneration. In Nicotiana tabacum, the final stage of maturation of the embyro sac is concomitant with the accumulation of calcium in the nucellar tissue surrounding the micropylar canal (Tian and Russel, 1997). This extracellular calcium may serve as a chemotropic attractant to the pollen tube (Reger et al, 1992) and may ultimately enter the synergid increasing its intracellular calcium content. After examining synergid degeneration in pearl millet, which occurs in the absence of pollination, Chaubal and Reger (1994) proposed that calcium moving from the apoplast of nucellar tissue surrounding the embryo sac enters the endoplasmic reticulum and numerous small vacuoles present in the synergids. When vacuoles are saturated with calcium, calcium is diverted, perhaps via the endoplasmic reticulum, to the nucleus, which then loses its nucleolus and degenerates. These observations implicate calcium influx as an effector or synergid death, perhaps via the activation of proteases, endonucleases, or signal transduction pathways as occurs during apoptosis in certain animal systems (McConkey and Orrenius, 1995). Isolated embryo sacs (Huang et al, 1992) and ovules (Jensen et al, 1977) may represent useful systems for pharmacological studies aimed at exploring the roles of calcium, and other factors, in the death of synergids.

\section{Degeneration of the suspensor}

The developing embryo may play a role in pcd of the neighboring suspensor. After fertilization, the zygote in flowering plants usually divides to form a basal cell and a terminal cell. The embryo develops from the terminal cell, while the basal cell undergoes a few relatively rapid divisions to form the suspensor. The suspensor plays an active role in the early promotion of the growth of the embryo proper (reviewed by Schwartz et al, 1997). During late stages of 
embryo growth, however, the suspensor degenerates. The degenerating cells of Phaseolus and Tropaeolum suspensors contain numerous and varied vesicles surrounded by 2,4 or even 8 membranes (Nagl, 1976). These appear to be autophagic vesicles where the included cytoplasm exhibits degenerative changes. Later during autolysis, large autolytic vacuoles form and membrane whorls appear to be released into these vacuoles. Eventually the vacuole lyses and the protoplast becomes disorganized. Nuclei, along with plastids, appear most resistant to degradation, being destroyed only after the tonoplast ruptures (Gartner and Nagl, 1990). The cell morphology described for degenerating suspensors is consistent with autophagic cell death, indicating that the chromatin pycnosis observed by Nagl (1976) is probably part of a nonapoptotic pathway. In Phaseolus and Tropaeolum suspensors, the progression of autolysis exhibits polarity, beginning in cells at the basal end of the organ and proceeding toward the embryo (Nagl, 1976). Acid phosphatase (Nagl, 1977; Singh et al, 1980) and $\beta$-glucosidase (Singh et al, 1980) activities increase during suspensor autolysis. It has been proposed that the lysed material may be mobilized for use by the embryo (Nagl, 1976).

Arrested embryo growth or destruction of embryos often results in abnormally vigorous growth of suspensors (Yeung and Meinke, 1993, and references therein), including, in the embryo-defective mutant of Arabidopsis, twin, the growth of a second embryo from transformed cells within the suspensor (Vernon and Meinke, 1994). Twin and other embryo-defective suspensor mutants delay their autolysis program and replace it with a more embryo-like program (Yeung and Meinke, 1993). Hence the presence of a normally developing embryo proper apparently restricts growth of the suspensor and may provide the signal(s) for the induction of the cell death pathway in suspensors. Further analysis of embryo-defective mutants may provide clues leading to the initiators of pcd in the suspensor.

\section{Death during vegetative growth}

From seed germination through maturation and senescence, several examples of pcd, can be found during vegetative growth. One dramatic example is provided by the foliar tissue sculpting that leads to the production of fenestrated leaves in Monstera species. The fenestrated morphology results from the death of just a few cells in the developing leaf primordia. These areas then expand along with the growing leaf resulting in a perforated lamina. Although some morphological and physiological aspects of this process have been characterized (Melville and Wrigley, 1968), nothing is known about the molecular biology of this interesting phenomenon. In contrast, more extensive information is available on the biology of cell death programs engaged during germination, vascular differentiation, and stress- and age-dependent death of mature tissues and organs, and these processes are discussed below.

\section{Aleurone death}

In some species, seed germination is accompanied by cell death in the aleurone layer (Reid and Meier, 1972; Kuo et al,
1996). The aleurone functions during germination by secreting hydrolases for mobilization of stored seed reserves and this aspect of aleurone physiology has been extensively studied (reviewed by Jones and Jacobsen, 1991). Both cysteine and aspartic acid proteinases localize to vacuoles in barley aleurone (Okita and Rogers, 1996, and references therein). Less is known, however, about the aleurone pcd pathway. Cell death in aleurone and endosperm cells during germination of seeds appears to involve autophagic vacuoles (Vigil, 1970; Reid and Meier, 1972), and, in wheat aleurone, is preceded by an increase in cytosolic calcium levels (Kuo et al, 1996). It was also recently discovered that death of wheat aleurone cells is prevented by treatment with okadaic acid and hence appears to depend on protein phosphatase activity (Kuo et al, 1996). Further probing of the wheat aleurone system with pharmacological agents may identify other components of the aleurone cell death pathway.

\section{Pith autolysis}

Under certain conditions the autolysis and disappearance of cortex or pith parenchyma cells leads to the formation of lysigenous aerenchyma, i.e. stems or roots containing large air-filled cavities (Armstrong and Armstrong, 1994). Stem pith autolysis is a widespread phenomenon (Carr et al, 1995), that in some species is positively correlated with rapid stem elongation and increasing sink strength of reproductive structures (Carr and Jaffe, 1995). Temperature- (Lu et al, 1991), drought- (Aloni and Pressman, 1981), hypoxia(McPherson, 1939 , as reviewed by Kawase, 1979) and $N$ or $\mathrm{P}$ deficiency-induced (He et al, 1994) root and stem pith autolysis have also been described.

In roots of maize ( $\mathrm{He}$ et al, 1996) and sunflower (Kawase and Whitmoyer, 1980) and stems of numerous herbaceous plants (Kawase, 1981, and references therein) hypoxia induces aerenchyma formation that is thought to facilitate the diffusion of oxygen from normoxic portions of the plant to hypoxic tissues. In maize ( $\mathrm{He}$ et al, 1996) and sunflower (Kawase, 1981), the requirement for hypoxia can be replaced by treatment with ethylene. He et al (1996) found it possible to modify transduction of the ethylene signal using second messenger antagonists. These authors concluded that an increase in intracellular calcium is necessary for cell death. He et al (1996) also found that contrary to its effect on aleurone death (see above) okadaic acid promoted cell death.

Cellulase activity appears to be a valid biochemical marker for lysigenous cavity formation (Kawase, 1981; Huberman et al, 1993; He et al, 1996), and it may act with other cell-degrading enzymes in a coordinated cell death program ( $\mathrm{He}$ et al, 1996). Although the localization and timing of cellulase gene expression and activity relative to dying cells need to be more rigorously determined, the apparent coupling of cellulase activity and autolysis of maize root cells (He et al, 1996) is consistent with the observation that application of cellulase to detached stems of numerous plant species induces aerenchyma formation (Kawase, 1981). Polygalacturonase (Huberman et al, 1993) and $\alpha$-amylase (Davis, 1985) activities are also increased during lysigenous cavity formation. 
Lu et al (1991) and Niki et al (1995) have characterized the temperature-sensitive formation of lysigenous cavities in the roots of pea. The pithlike central xylem parenchyma cells of pea roots differentiate normally under the permissive temperature (less than $15^{\circ} \mathrm{C}$ ) to form late maturing metaxylem tracheary elements, but often autolyse to form cavities at nonpermissive temperatures. Cell degeneration in developing pea root vascular cavities is characterized by the following sequence of events: loss of tonoplast, appearance of electron-dense inclusions in the nucleus, swelling and loss of organellar integrity, thinning of the cell wall and plasma membrane breakdown (Niki et al, 1995). Protoplast breakdown also precedes the disappearance of the cell wall during drought-induced tomato stem pith autolysis (Aloni and Pressman, 1981). Niki et al (1995) suggested that pea vascular cavity formation could be the result of (a) misdirected lysis due to hydrolytic enzymes produced in adjacent autolysing tracheary elements, or (b) the initiation of a premature tracheary element death program. The latter possibility raises the interesting question of whether the tracheary element death program exists as a parallel pathway that can be uncoupled from the normally preceding events of cell wall thickening and lignification (Fukuda, 1997, this issue).

\section{Differentiation of tracheary elements and fiber-sclereids}

Over the last 15 years, experimental systems optimized for tracheary element differentiation have received increasing attention as model systems for studying plant pcd. The ontogeny of tracheary elements and fiber-sclereids terminates with the production of a thickened cell wall that is usually lignified. The thickened secondary cell walls of both tracheary elements and fiber-sclereids provide support and flexibility and often lack a protoplast at maturity. In the xylem, tracheary elements are joined end-to-end in long continuous tubes and serve as the water-conducting tissue of the vascular system. The xylem is typically spacially associated with the phloem, the principle food-conducting tissue of vascular plants. A method for studying sclereid development in Arabidopsis was recently presented (Lev-Yadun, 1994) and may represent an opportunity for the development of an additional experimental system for the molecular genetics of plant pcd. The death of water-storage cells in the xeromorphic leaves of certain species of Sanseveria and Oncidium is another example of terminal differentiation resulting in persistent modified cell walls that lack protoplasts (Koller and Rost, 1988). Details of the biochemistry and molecular biology of fiber-sclereid and water-storage cell pcd are not known, although it has been suggested that fibersclereids and tracheary elements share genetic pathways leading to their differentiation (Esau, 1965; Savidge, 1983). Experimental systems, most notably the Zinnia mesophyll cell culture system (Kohlenbach and Schmidt, 1975; Fukuda and Komamine, 1980), have been developed for in vitro induction of tracheary element differentiation from parenchyma cells. The ease of identification of tracheary elements, with their distinctive cell wall thickenings, and the semisynchronous autolysis of cultured differentiating Zinnia tracheary elements has made this an especially accessible system for pharmacological studies and for the cloning of tracheary element and pcd cDNAs.

While some indirect evidence for DNA fragmentation during tracheary element pcd has been presented (Mittler et al, 1995; Wang et al, 1996), the ontogeny of intracellular disorganization does not mirror that of mammalian cell apoptosis (Groover et al, 1997). Rather, death of tracheary elements more closely resembles that occurring in cells of senescent leaves, where extensive cellular disorganization is the last event, apparently following tonoplast lysis (Thomson and Platt-Aloia, 1987; Fukuda, 1996; Jones and Dangl, 1996). Whether the release of hydrolytic enzymes following tonoplast rupture is the primary cause or a secondary effect of pcd has not been established (Thompson and Platt-Aloia, 1987; Jones and Dangl, 1996).

Although no genes or proteins controlling the initiation of the autolytic phase of tracheary element differentiation have been identified, hydrolytic enzyme activity increases dramatically late in the differentiation process. Markers for autolysis include an endonuclease (Thelen and Northcote, 1989), an RNAse (Ye and Droste, 1996) and proteases (Minami and Fukuda, 1995; Ye and Varner, 1996; Beers and Freeman, 1997). Activities of both cysteine and serine proteases increase late in the differentiation process. The enzymes have been partially characterized using model substrates in vitro, but their in vivo substrates have not been identified. Localization of these proteases has not been determined; however, the sequence encoding the prepropeptide for at least one cysteine protease is consistent with vacuolar residence (Ye and Varner, 1996). Cysteine and serine protease inhibitors are known to inhibit apoptosis in several model systems (Kumar and Lavin, 1996). Cysteine protease inhibitors also block tracheary element differentiation if applied before wall thickenings are detected (Fukuda, 1996). The ubiquitin-dependent pathway of proteolysis may also be required for vascular development, as the overexpression in transgenic tobacco of a mutant form of ubiquitin unable to form polyubiquitin chains resulted in aberrant vascular development (Bachmair et al, 1990). While these results point to roles for cysteine proteases and perhaps ubiquitin-protein conjugation as mediators of tracheary element differentiation, they do not specifically address the role of proteases in the regulation of plant pcd.

The retention, in situ, of protoplasts by some tracheary elements and fiber-sclereids (Esau, 1965) indicates that pcd can be uncoupled from the differentiation process. It is not known, however, whether death is dependent on signals generated during tracheary element differentiation or results from the activity of an independent parallel pathway. Initiation of a premature tracheary element death program (i.e. autolysis in the absence of cell wall modification) has been proposed as one explanation for autolysis of cells occurring in the vascular cavity of pea roots (Niki et al, 1995). Conclusive experimental evidence demonstrating that the tracheary element cell death program can be activated independent of cell wall thickening and lignification is lacking, however. It is not known whether the tracheary element cell death program, 
or components thereof, are active during other pcd events in plants.

\section{Selective autolysis of sieve elements}

Sieve elements are the principle conduit for the movement of assimilates through the phloem and they exhibit a unique selective autolysis during their differentiation (see Sjolund, 1997, for a recent review). Although mature sieve elements retain their protoplast, selective autolysis results in the degradation of the nucleus, the tonoplast, ribosomes, dicytosomes and microtubules. The endoplasmic reticulum persists as do plastids and mitochondria in many species, although the latter two organelle types are usually modified (Esau, 1965). During sieve element differentiation in Ephedra, pycnotic degeneration of the nucleus is detectable just prior to the decline of populations of dictyosomes and ribosomes and collapse of the tonoplast (Cresson and Evert, 1994). Chromatin pycnosis was also noted in differentiating sieve elements of Mimosa (Esau, 1972) and in wheat (Eleftheriou, 1986). Although electron micrographs prepared from Ephedra and Mimosa documented nuclear pycnosis similar to that occurring in nonapoptotic pcd (Schwartz, 1992), chromatin pycnosis and nuclear morphology in wheat sieve elements were identical to that reported for apoptotic nuclei (Kerr and Harmon, 1991), including lobing and fragmentation. The envelope of the degrading nucleus in sieve elements is also closely associated with endoplasmic reticulum cisternae (Esau, 1972). It was suggested that the endoplasmic reticulum may serve as a source of acid phosphatase (Oparka et al, 1981) involved in autolysis.

Ubiquitin-dependent proteolysis may be important to sieve element differentiation. A cDNA encoding polyubiquitin protein has been cloned from pine phloem (Alosi-Carter et al, 1995), and immunoblot analysis has demonstrated the presence of ubiquitin protein in phloem exudate (Schobert et al, 1995). In vivo, however, ubiquitin may be inactivated by trypsin-like activity catalyzing the removal of the $C$-terminal gly-gly (Wilkinson, 1988). This modification is not detectable by SDS-PAGE or immunoblot analysis and hence the presence of immunologically reactive ubiquitin in sieve elements does not establish pathway activity. The detection of other proteolytic systems active during sieve element differentiation has not been reported. A Streptanthus tortuosus tissue culture system developed for the characterization of proteins present in differentiated sieve elements (Wang et al, 1995) has led to the identification of $\beta$-amylase as a sieve element marker and may prove useful for identifying additional biochemical and molecular markers for this unique selective autolysis.

\section{Abscission}

Sexton and Roberts (1982) noted that abscission is sometimes erroneously referred to as a process requiring cell senescence or degeneration. Abscission is a phenomenon affecting leaves, flowers, fruits, branches and bark that results both in the separation of these organs from the parent body without injury to living tissue and in the protection of the newly exposed tissue, via suberization and lignification (Esau,
1965). This shedding of organs is a normal process usually occurring after the mature organ has degenerated (see leaf and flower senescence below) or following fruit ripening. Alternatively, premature abscission may be induced following stress (Williams and Whitham, 1986; Morgan et al, 1990). Separation of organs from the parent plant follows dissolution of cell walls in a few layers of specialized cells, known as the abscission zone, usually at the base of the abscising organ (Sexton and Roberts, 1982). Three types of breakdown are listed by Addicott and Lynch (1955): (1) the removal of the middle lamella, (2) removal of the middle lamella and part of the primary cell wall, and (3) separation of entire cells. The enzymes responsible for cell separation include cellulases (Sexton et al, 1980; del Campillo et al, 1990; Brummell et al, 1994) and polygalacturonases (Taylor et al, 1990; Kalaitzis et al, 1995). In dicotyledonous plants, abscission is accelerated by ethylene and inhibited by auxin (Abeles, 1968) and brassinolide (Iwahori et al, 1990). A precise understanding of the role of these and other signaling molecules (Thompson and Osborne, 1994) regulating abscission would have important implications for crop production.

Despite the occurrence of pith autolysis during Phaseolus leaf abscission (Webster, 1970), other anatomical and ultrastructural changes occurring in the layer of cells where organ separation occurs are not consistent with pcd directly participating in abscission. On the contrary, abscission zone cells are apparently metabolically active at the time of organ shedding. Abscission zone cells contain more organelles (Goren et al, 1984) and exhibit greater secretory activity (Ramina et al, 1989) than neighboring cells. Moreover, in the case of Phaseolus leaves (Webster, 1970) and citrus fruit (Goren et al, 1984), events leading to abscission include an increase in cell division and cell enlargement in the abscission zone. In Phaseolus, it is the thin walled, newly dividing cells through which separation takes place, and nuclei in these cells are intact and often still dividing when separation occurs and cell contents are lost (Webster, 1970). Separation in peach leaf abscission zone occurs when digestion of the outer thicker wall, rather than thin walls produced by secondary cell division, leads to cell breakage and the release of cytoplasm (Ramina et al, 1989). Intracellular separation occurs after the dissolution of cell wall components in citrus leaf abscission zones, while plasmalemma and tonoplasts of separation layer cells remained intact throughout abscission (Goren et al, 1984).

The above observations considered with the fact that the cellulosic and polygalcturonate components of the cell wall are responsible for support and adhesion, respectively, suggest that the action of cell wall lytic enzymes leading to dissolution and/or mechanical cell wall disruption in the separation layer is necessary and sufficient for organ shedding to occur. Degeneration of the cytoplasm in the separation layer does not appear to be necessary and, in fact, may be disadvantageous, as continued synthesis and secretion of lytic enzymes by metabolically active cells are likely to favor organ separation. The competence of stem pith to initiate autolysis following cellulase or ethylene treatment (described above) indicates that pith autolysis observed in the abscission zones of Phaseolus may have been a secondary effect induced by external factors, such 
as cellulase, originating in the separation layer. Pith autolysis, therefore, may not be necessary for organ shedding in Phaseolus (Webster, 1970). That dissolution of cell wall material appears to be sufficient to ensure organ shedding does not exclude the possibility that examination of additional experimental systems may reveal conclusive examples of pcd in the separation layer of abscising organs.

Conflicting results have emerged concerning the involvement of pcd in the abscission of root-cap cells. Abscission of single root-cap cells occurs beneath the soil surface where mucilage-coated cells are lost and replaced at the root-cap meristem. Phaseolus root-cap cells contain high levels of hydrolytic enzymes (Thomas et al, 1977), as do senescing plant organs and autolysing tracheary elements. Histological evidence that fragmented nuclei are present in root-cap cells has also been presented (Wang et al, 1996). Despite these observations supporting pcd of root-cap cells, cultured detached maize root-cap cells remain alive without dividing for up to three months (McCully, 1989, and references therein). It has been suggested that partially separated root-cap cells are involved in transducing signals controlling hydrotropic and thigmotropic responses, and that live separated cells are engaged in regulating bacterial growth in the rhizosphere (McCully, 1989). Perhaps a division of labor exists among root-cap cells requiring death of only a subset of cells, or if separation occurs prematurely or inappropriately.

\section{Senescence}

The physiological and biochemical events that comprise agedependent senescence represent a controlled remobilization of intracellular components for export to plant storage tissues and/or reproductive structures. In leaves, extensive cellular disorganization and cell death occur only after the majority of starch and protein have been remobilized (Wittenbach et al, 1982; Thomson and Platt-Aloia, 1987), suggesting that it may be possible to uncouple cell death from the remobilization phase of senescence. The ultrastructure, biochemistry and molecular biology related to remobilization have been extensively characterized. In contrast, relatively little is known about the control of cell death during senescence. Senescence of ripening fruits (see Hadfield and Bennett, 1997, this issue), leaves (see reviews by Thomas and Stoddart, 1980; Kelly and Davies, 1988; Smart, 1994) and flower parts (petal senescence was reviewed by Borochov and Woodson, 1989) is developmentally regulated. Senesence can also be induced by environmental stress or experimentally in both detached and attached organs. As with abscission and pith autolysis, ethylene can accelerate the senescence process in many species. Cytokinins have an effect opposite to that of ethylene and in many species are capable of delaying (Gan and Amasino, 1995) or even reversing senescence (Smart, 1994). Naturally occurring leaf senescence is an orderly, and sometimes slow, process. For example, the near complete loss of chlorophyll from senescing soybean leaves, which begins approximately 4 weeks after flowering, is accomplished over a 6 week period (Wittenbach et al, 1980). During soybean leaf senescence, approximately $80 \%$ of starch and $90 \%$ of soluble protein are lost from the leaves. Leaf breakdown products are rapidly translocated to sink tissues such as fruits, stems, or roots. Senescence of flower petals and detached leaves can proceed more rapidly, terminating in just a few days. Senescence can be inhibited by anaerobic conditions and cycloheximide (Martin and Thimann, 1972; Valpuesta et al, 1995); hence, it is an active degradative process which requires de novo protein synthesis.

Ultrastructural analyses indicate that chloroplasts and other organelles remain intact throughout senescence (Thomson and Platt-Aloia, 1987). Intact chloroplasts can be isolated from protoplasts prepared from dark-induced senescent wheat leaves from which up to $80 \%$ of the chlorophyll and protein have been lost (Wittenbach et al, 1982). Wittenbach et al (1982) suggested that autophagy of chloroplasts within the intact vacuole may be occurring during soybean leaf senescence. Respiratory activities of the mitochondria and catabolic activities of peroxisomes increase or remain steady during senescence (Smart, 1994) and mitochrondria remain intact. The endoplasmic reticulum appears at least partially labile during senescence, while the nucleus appears to remain intact up to an advanced stage of chlorophyll loss (Thomson and Platt-Aloia, 1987). It is possible to isolate intact vacuoles from senescing leaves (Wittenbach et al, 1982). Moreover, that leaves remain turgid until advanced senescence provides indirect evidence for the persistence of an intact tonoplast (Smart, 1994). Thus it appears that the organized disassembly program active in leaves during senescence maintains cellular compartmentation throughout most of senescence, with death occurring semisynchronously only at the very end of the process (Thomson and Platt-Aloia, 1987). In contrast, petal senescence is characterized by early wilting (Matile and Winkenbach, 1971; Smith et al, 1992) and/or a watersoaked appearance, indicating the loss of tonoplast integrity. Ultrastructural changes in senescing carnation petals confirm this apparent cellular disorganization including early rupture of the tonoplast and plasmalemma and dissolution of cell wall components leading to complete loss of cellular contents (Smith et al, 1992). Autophagic activity of vacuoles has also been noted in senescing petals (Matile and Winkenbach, 1971).

Hydrolytic enzyme activity increases during senescence, and much attention has been focused on the role of proteases during senescence. Numerous biochemical characterizations of increased proteolytic activity during senescence have been presented (Matile and Winkenbach, 1971; Martin and Thimann, 1972; Drivdahl and Thimann, 1977; Wittenbach et al, 1980, 1982; Miller and Huffaker, 1982; and reviewed by Feller, 1986), including evidence for activity of both thiol (Miller and Huffaker, 1982; Drivdhal and Thimann, 1977) and serine proteases (Miller and Huffaker, 1982). Further support for an important role for proteases in leaf senescence has come from the identification of senescence-related genes. Several investigators characterizing cDNA libraries from senescing leaves (Hensel et al, 1993; Lohman et al, 1994; Smart et al, 1995; Drake et al, 1996) and flower petals (Jones et al, 
1995; Valpuesta et al, 1995) have identified sequences with homology to cysteine proteases.

In leaves, the vast majority of protease activity detectable with model substrates appears to localize to the large central vacuole (Boller and Kende, 1979; Wittenbach et al, 1982; Canut et al, 1987); and hence, senescence-related proteases are likely to be vacuolar. Because this acidic compartment exhibits the ability to regulate the degradation of included protein (Canut et al, 1986; also reviewed by Staswick, 1994; and by Herman, 1994), it is possible that some mechanism, not yet described, exists for transport of senescence-targeted proteins to the vacuole and their subsequent degradation in that organelle. That plastids contains $>60 \%$ of intracellular leaf protein suggests involvement of plastidic proteinases in remobilization of $\mathrm{N}$ during senescence (reviewed by Dalling and Nettleton, 1986). Chloroplastic ATP-dependent (Malek et al, 1984; Liu and Jagendorf, 1986) and non-ATP-dependent proteases (Bushnell et al, 1993) have been detected. However, one candidate for the ATP-dependent activity (the $E$. coli homolog ClpP system) is expressed constitutively and therefore does not appear to be a senescence-related protease (Shanklin et al, 1995).

Recent work provides a strong link between the cytosolic/nuclear-localized ubiquitin pathway of proteolysis and leaf senescence. Genschik et al (1994) found that senescing tobacco accumulated high levels of mRNA encoding two different ubiquitin carrier proteins (E2s), homologous to Ubc4At4a and Ubc4At4b, and a polyubiquitin gene. Using a GUS reporter construct, Garbarino and Belknap (1994) followed the expression of the ubiquitin-ribosomal protein fusion gene, ubi3, during potato leaf maturation. Activity was highest in meristematic tissues, declined during leaf expansion and rose again to near meristematic levels in senescent leaves. As rRNA content decreases during senescence (Makrides and Goldthwaite, 1981), increased ubi3 expression during senescence may reflect a need for a higher level of ubiquitin for protein degradation rather than a need for higher levels of ribosomal proteins for senescence-related gene expression. The investigations described above indicate that multiple proteolytic systems are induced late in the senescence process; however, such experiments do not specifically address the role of proteolysis as a regulator of the commitment to senescence and/or cell death.

As senescence of organs is followed by abscission, which serves to remove from the parent plant cells that are no longer needed, the purpose served by a cell death program in senescing tissues is not readily apparent. The endogenously controlled intracellular deterioration that occurs during organ senescence may be sufficient to cause cell death (Nooden, 1988). Perhaps, therefore, the entire senescence process should be considered a unique cell death program. It remains possible, however, that

Table 1 Summary of programmed cell death during plant growth and development

\begin{tabular}{|c|c|c|c|c|c|}
\hline & $\begin{array}{l}\text { Biochemical and } \\
\text { molecular markers }\end{array}$ & $\begin{array}{l}\text { Vacuolar rupture } \\
\text { precedes } \\
\text { complete cellular } \\
\text { disorganization }\end{array}$ & $\begin{array}{l}\text { Autophagic } \\
\text { vesicles } \\
\text { reported }\end{array}$ & $\begin{array}{l}\text { Chromatin } \\
\text { pycnosis } \\
\text { reported }\end{array}$ & Cell fate ${ }^{2}$ \\
\hline Sex organ abortion ${ }^{1}$ & $\begin{array}{l}\text { Ts2/Gsf1 (hydroxysteroid } \\
\text { dehydrogenases) }\end{array}$ & $?$ & no & no & 2 \\
\hline Anther dehiscence & $\begin{array}{l}\text { Cellulase, ubiquitin, } \\
\text { TA56 (cysteine protease) }\end{array}$ & $?$ & no & no & 2 \\
\hline Death of incompatible pollen & S-RNases & ? & no & no & 3 \\
\hline Degeneration of haploid megaspores & $?$ & ? & no & yes & 2 \\
\hline Synergid death & nuclear calcium increase & yes & no & no & 2 \\
\hline Suspensor death & $\begin{array}{l}\text { acid phosphatase, } \\
\beta \text {-glucosidase }\end{array}$ & yes & yes & yes & 1,2 \\
\hline Aleurone/endosperm death & $\begin{array}{l}\text { intracellular calcium increase, } \\
\text { protein phospatase } \\
\text { (aleurone death prevented } \\
\text { by phosphatase inhibitor) }\end{array}$ & $?$ & yes & no & 1,3 \\
\hline Pith autolysis & $\begin{array}{l}\text { cellulase, } \alpha \text {-amylase } \\
\text { polygalacturonase, } \\
\text { intracellular calcium increase, } \\
\text { protein phosporylation } \\
\text { (death prevented by kinase } \\
\text { inhibitor, death promoted by } \\
\text { phosphatase inhibitor) }\end{array}$ & yes & no & no & 1 \\
\hline Tracheary element autolysis & $\begin{array}{l}\text { nucleases, proteases, } \\
\text { ubiquitin }\end{array}$ & yes & no & no & 3 \\
\hline Sieve element selective autolysis & $\beta$-amylase, ubiquitin & $\begin{array}{l}\text { yes, but autolysis } \\
\text { is selective }\end{array}$ & no & yes & $\begin{array}{l}3 \text { (with } \\
\text { protoplast) }\end{array}$ \\
\hline Senescence & $\begin{array}{l}\text { nucleases, proteases, } \\
\text { carbohydrases, ubiquitin, } \\
\text { ubiquitin conjugating enzymes }\end{array}$ & yes & yes & no & 4 \\
\hline
\end{tabular}

\footnotetext{
${ }^{1}$ See text for references. ${ }^{2}$ Cell fate as indicated in figure 1
} 
death is due to a separate pcd pathway active in concert with remobilization of cellular components. If so, the identification of molecular markers for plant pcd would help to reveal (a) the point during senescence at which pcd is initiated, (b) whether the senescence pcd pathway shares elements with other plant pcd pathways, and (c) whether cell death can be uncoupled from the preceding events of senescence.

\section{Conclusion}

This review has described cell death that is initiated by stress, such as hypoxia-induced aerenchyma formation, and cell death that appears to depend on communication between neighboring cells, such as (a) incompatible pollen tube death, (b) suspensor degeneration, and (c) synergid death in some species (Table 1). Also described was pcd as it signifies the terminal differentiation of cells in anthers, xylem, and senescing leaves. Some of the processes considered in this review are arguably not examples of cell suicide. The death of incompatible pollen tubes is perhaps better described as cell murder where the victim is somehow prevented from protecting itself from lethal external factors (Martin, 1993). The unique selective autolysis occurring during sieve element maturation is neither suicide nor murder, but produces an enucleate protoplast.

The genes responsible for initiation of plant cell suicide programs are unknown. Sequences with identity to the highly conserved inhibitors of animal pcd, e.g. the Caenorhabditis elegans ced-9 (Hengartner et al, 1992) and human $b c l-2 / B a x$ (reviewed by Rubin et al, 1994) have not been retrieved from the expressed sequence tags (ESTs) from plant sources. However, Arabidopsis and rice do express a protein similar to DAD-1, a recently identified animal pcd supressor, suggesting that plants and animals do share certain components of pcd pathways (Sugimoto et al, 1995). Cloning of genes sharing identity with members of the cell death-promoting caspase protease family (Alnemri et al, 1996) has not been reported for plants. Some members of this family (e.g., caspase 3, Tewari et al, 1995) cleave poly(ADP-ribose) polymerase (PARP), a nuclear enzyme found in most eukaryotes, including plants (Lepiniec et al, 1995). Hence assays for PARP-cleaving activity and sensitivity of plant pcd to peptidic caspase inhibitors may reveal the presence in plants of homologs to animal cell death proteases. In addition, since the ubiquitin pathway is responsible for the degradation of some shortlived regulatory proteins (Hochstrasser, 1995), strategies
1

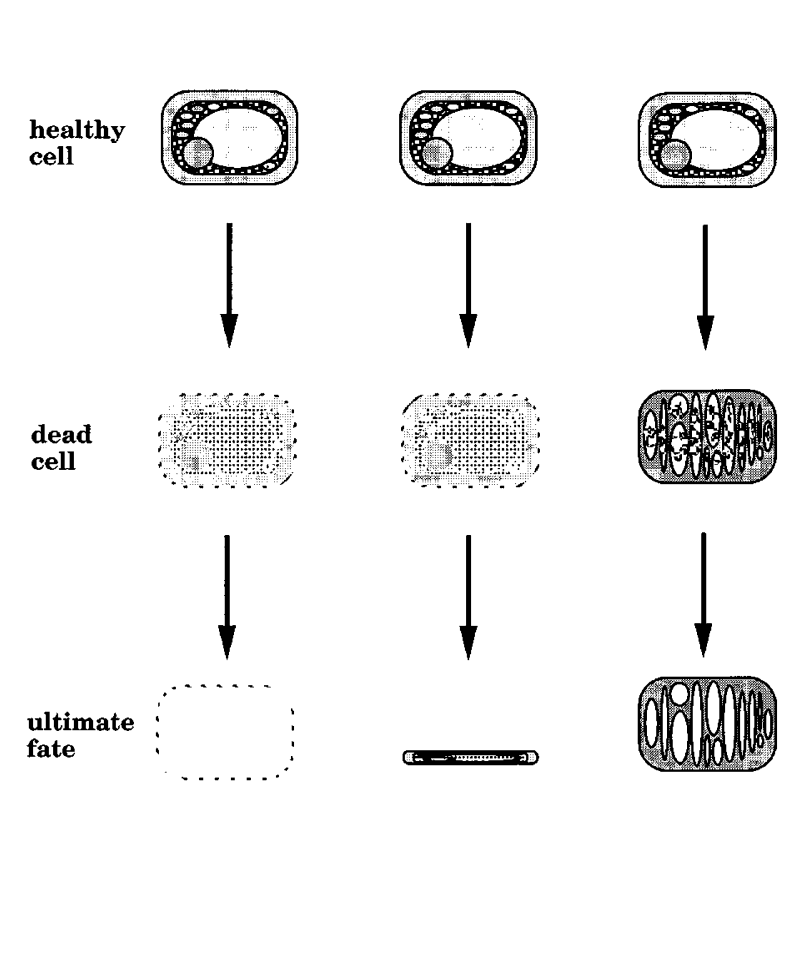

3

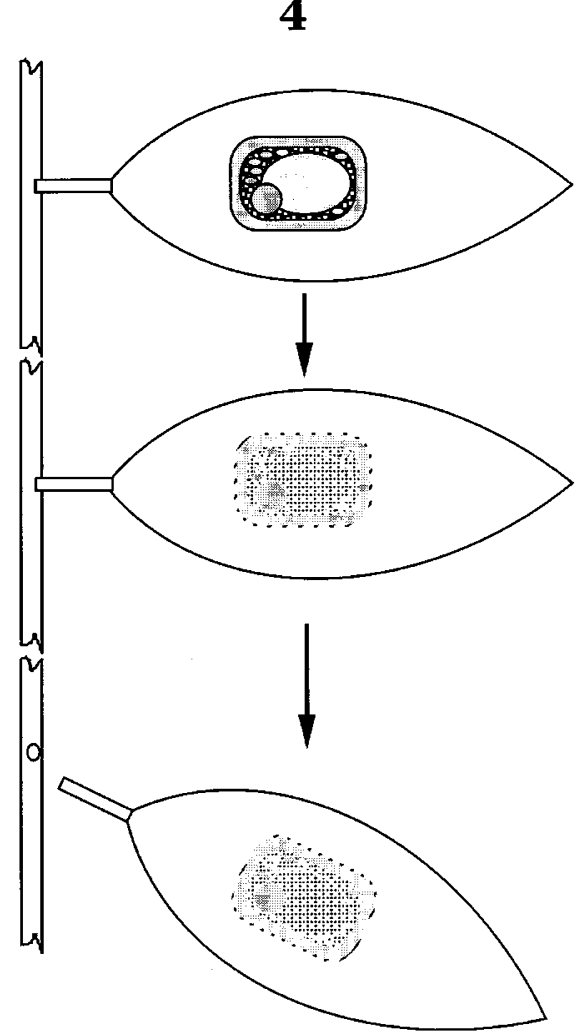

Figure 1 Cell fate following plant programmed cell death. Fate 1, both protoplasm and cell wall disappear completely after death. Precise details of complete cell removal are not yet known. Fate 2, cell death is followed by crushing or tearing of cell remnants by expanding neighboring cells. Fate 3 , cell wall persists following protoplast death. In some cases, the wall is modified by thickening and lignification, as in the mature tracheary element shown here. Fate 4 , cell death follows the ordered remobilization of cellular components during senescence, and organs consisting of dead cells are then shed from the parent plant (cell and leaf are not drawn to scale) 
aimed at identifying nuclear proteins whose ubiquitindependent turnover promotes pcd may also prove fruitful. Finally, molecular genetic approaches using, for example, embryo-defective suspensor mutants (Vernon and Meinke, 1994) and sex-determination mutants (DeLong et al, 1993) may also identify genes controlling plant pcd.

In animals, heterophagic elimination of dead cells (phagocytosis by adjacent cells) is a prominant characteristic of apoptotic cell death (Clarke, 1990). Heterophagy is less important following nonapoptotic cell death, which relies more on autophagic and autolytic mechanisms. While the potential for phagocytosis of apoptotic bodies by plant cells could be explored using protoplast experimental systems, such as that described by Wang et al (1996), heterophagy of wall-bounded plant cells has not been reported. Four fates for plant cells during pcd are presented in Figure 1: (1) complete disappearance of cells, including cell walls (e.g., during aerenchyma formation and the production of fenestrated leaves (Melville and Wrigley, 1968)), (2) crushing, tearing or overgrowth of death cells by their expanding neighbors, as in the case of megaspore development, (3) persistence of cell walls with or without degraded components of dead protoplast (e.g., mature tracheary elements), and (4) post-senescence shedding of entire organs or tissues consisting of dead cells. That autolysis and perhaps autophagy rather than heterophagy appear to be the predominant mechanisms employed during both the suicide and the elimination of plant cells may in part be due to the presence of the plant cell wall. Autolysis does not rule out a role for microphagy of proteins and other soluble components released by dead cells (Herman, 1994), but the presence of the cell wall clearly presents a barrier to macrophagy by adjacent cells. It seems reasonable to assume, therefore, that, by necessity, plant cells employ controlled autolytic methods leading to the 4 cell fates shown in Figure 1.

Although apoptosis does not appear to be a universal mechanism for pcd in plants, certain elements of apoptosis have been detected during some plant pcd processes. Fragmentation of nuclear DNA during apoptosis may be catalyzed by a calcium-dependent nuclease (Wyllie et al, 1980). Calcium influx appears to trigger nuclear degeneration in degenerating synergids (Chaubal and Reger, 1994). Evidence for DNA fragmentation during pathogen-induced pcd (Ryerson and Heath, 1996), tracheary element differentiation (Mittler et al, 1995) and root-cap cell shedding (Wang et al, 1996) has been presented. To date, however, host-selective phytotoxin-induced pcd exhibits the most apoptotic-like characteristics, including calcium-enhanced DNA laddering, lobing or fragmentating nuclei and lobing cells separating into apoptotic bodies (Wang et al, 1996). These events were characterized at the biochemical and light microscope levels. It would be interesting to view electron micrographs of the phytotoxininduced process in comparison with apoptotic animal cells. Nuclear pycnosis, visualized at the electron microscope level, has been reported to be part of three additional plant cell death programs occurring in intact plants: haploid megaspore degeneration (Bell, 1996), suspensor degeneration (Nagl, 1976) and sieve element enucleation
(Eleftheriou, 1986; Cresson and Evert, 1994). Of these three, however, only the pycnotic nuclei of wheat sieve elements described by Eleftheriou (1986) contained dense masses of sharply delineated chromatin visible in lobing and fragmenting nuclei, i.e. pycnosis truly characteristic of apoptosis. While further examination of the biochemistry of the degeneration of haploid megaspores, synergids and suspensors and of the selective autolysis of sieve elements may reveal additional apoptotic-like qualitites in these processes, the observed autolytic and autophagic mechanisms active during the killing and elimination of dead cells during pith autolysis, tracheary element differentiation and senescence support the conclusion that nonapoptotic pcd pathways are essential components of normal plant growth and development.

\section{Acknowledgements}

I would like to thank Raj Chaubal, Daniel Gallie, Daniel Gladish and Richard Sjolund for helpful discussions; and Dan Gladish, Kay RobinsonBeers, Bonnie Woffenden and Thomas Freeman for comments on the manuscript. I thank Stephen Dellaporta, Alan Jones, David Meinke and Scott Russell for providing preprints.

\section{References}

Abeles FB (1968) The role of RNA and protein synthesis in abscission. Plant Physiol. 43: $1577-1586$

AddicottFT and Lynch RS (1995) Physiology of abscission. Annu. Rev. PlantPhysiol. 6: $211-238$

Alnemri ES, Livingston DJ, Nicholson DW, Salvesen G, Thornberry NA, Wong WW and Yuan J (1996) Human ICE/CED-3 protease nomenclature. Cell 87: 171

Aloni B and Pressman E (1981) Stem pithiness in tomato plants: the effect of water stress and the role of abscisic acid. Physiol. Plant. 51: 39-44

Alosi-Carter MC, Kulikauskas RM and Park RB (1995) Structure and expression of ubiquitin gene transcripts in pine. Can. J. For. Res. 25: 1-7

Armstrong J and Armstrong W (1994) Chlorophyll development in mature lysigenous and schizogenous root aerenchymas provides evidence of continuing cortical cell viability. New Phytol. 126: 493-497

Bachmair A, Becker F, Masterson RV and Schell J (1990) Perturbation of the ubiquitin system causes leaf curling, vascular tissue alteration and necrotic lesions in a higher plant. EMBO J. 9: 4543-4549

Beers EP and Freeman TB (1997) Proteinase activity during tracheary element differentiation in Zinnia mesophyll cultures. Plant Physiol. 113: 873-880

Bell PR (1996) Megaspore abortion: a consequence of selective apoptosis? Int. J. Plant Sci. 157: 1-7

Boller T and Kende $\mathrm{H}$ (1979) Hydrolytic enzymes in the central vacuole of plant cells. Plant Physiol. 63: 1123-1132

Bonner LJ and Dickinson HG (1989) Anther dehiscence in Lycoperisicon esculentum Mill. New Phytol. 113: 97-115

Borochov A and Woodson WR (1989) Physiology and biochemistry of flower petal senescence. Hort. Rev. 11: 15-43

Bracale M, Caporali E, Galli MG, Longo C, Marziani-Longo G, Rossi G, Spada A, Coave C, Falavigna A, Raffaldi F, Maestri E, Restivo FM and Tassi F (1991) Sex determination and differentiation in Asparagus officinalis L. Plant Sci. 80: 67-77

BrummelDA, Lashbrook CC and Bennett AB (1994) Plantendo-1,4- $\beta$-D-glucanases. In M.E. Himmel, J.O. Baker and R.P. Overend, eds, Enzymatic Conversion of Biomass for Fuels Production, American Chemical Society, Washington, D.C., 566: $100-129$

Bushnell TP, Bushnell D and Jagendorf AT (1993) A purified zinc protease of pea chloroplasts, EP1, degrades the large subunit of ribulose-1, 5-bisphosphate carboxylase/oxygenase. Plant Physiol. 103: 585-591

Canut H, Alibert G, Carrasco A and Boudet AM (1986) Rapid degeneration of abnormal proteins in vacuoles from Acerpseudoplatanus L. cells. Plant Physiol. 81: $460-463$ 
Canut H, Dupre M, Carrasco A and Boudet AM (1987) Proteases of Melilotus alba mesophyll protoplasts. Planta 170: $541-549$

Carr SM and Jaffe MJ (1995) Pith autolysis in herbaceous, dicotyledonous plants: experimental manipulation of pith autolysis in several cultivated species. Ann. Bot. 75: $587-592$

Carr SM, Seifert M, Delbaere B and Jaffe MJ (1995) Pith autolysis in herbaceous dicotyledonous plants. A physiological ecological study of pith autolysis under native conditions with special attention to the wild plant Impatiens capensis Meerb. Ann. Bot. 76: 177-189

Chaubal R and Reger BJ (1994) Dynamics of antimonate-precipitated calcium and degeneration in unpollinated pearl millet synergids after maturity. Sex. Plant Reprod. 7: 122-134

Cheng PC, Greyson RI and Walden DB (1983) Organ initiation and the development of unisexual flowers in the tassel and ear of Zea Mays. Amer. J. Bot. 70: 450-462

Clarke PGH (1990) Developmental cell death: morphological diversity and multiple mechanisms. Anat. Embryol. 181: 195-213

Cresson RA and Evert RF (1994) Development and ultrastructure of the primary phloem in the shoot of Ephedra Viridis (Ephedraceae). Amer. J. Bot. 81: 868877

Dalling MJ and Nettleton AM (1986) Chloroplast senescence and proteolytic enzymes. In M.J. Dalling, eds, Plant Proteolytic Enzymes, 2. CRC Press, Boca Raton, $125-153$

Davis BD (1985) Association of $\alpha$-amylase with cellular autolysis in pea stem tissues Amer. J. Bot. 72: 1902-1907

del Campillo E and Lewis LN (1992) Occurrence of the 9.5 cellulase and other hydrolases in flower reproductive organs undergoing major cell wall disruption. Plant Physiol. 99: 1015-1020

del Campillo E, Reid PD, Sexton R and Lewis LN (1990) Occurrence and localization of 9.5 cellulase in abscising and nonabscising tissues. Plant Cell 2: 245-254

Dellaporta SL and Calderon-Urrea A (1993) Sex determination in flowering plants. Plant Cell 5: $1241-1251$

DeLong A, Calderon-Urrea A and Dellaporta SL (1993) Sex determination gene TASSELSEED2 of maize encodes a short-chain alcohol dehydrogenase required for stage-specific floral organ abortion. Cell 74: 757-768

Dodds PN, Clarke AE and Newbigin E (1996) A molecular perspective on pollination in flowering plants. Cell 85: 141-144

Drake R, John I, Farrell A, Cooper W, Schuch W and Grierson D (1996) Isolation and analysis of $c D N A s$ encoding tomato cysteine proteases expressed during leaf senescence. Plant Molec. Biol. 30: 755-767

Drivdahl RH and Thimann KV (1977) Proteases of senescing oat leaves. Plant Physiol. 59: 1059-1063

Eleftheriou EP (1986) Ultrastructural studies on protophloem sieve elements in Triticum aestivum L. nuclear degeneration. J. of Ultrastruc. Molec. Struct. Res. 95: $47-60$

Ellis RE, Yuan J and Horvitz HR (1991) Mechanisms and functions of cell death. Annu. Rev. Cell Biol. 7: 663-698

Esau K (1965) Plant Anatomy, 2nd Ed., Wiley, New York.

Esau K (1972) Changes in the nucleus and the endoplasmic reticulum during differentiation of a sieve element in Mimosa pudica L. Amer. J. Bot. 36: 703-710

Feller U (1986) Proteolytic enzymes in relation to leaf senescence. In M.J. Dalling, eds, Plant Proteolytic Enzymes, 2. CRC Press, Boca Raton, Florida, 49-68

Fukuda $H$ (1997) Programmed cell death during vascular system formation. Cell Death Differ. 4: 684-688

Fukuda $\mathrm{H}$ and Komamine A (1980) Establishment of an experimental system for the study of tracheary element differentiation from single cells isolated from the mesophyll of Zinnia elegans. Plant Physiol. 65: 57-60

Fukuda HF (1996) Xylogenesis: initiation, progression, and cell death. Annu. Rev. Plant Physiol. Plant Molec. Biol. 47: 299-326

Gan S and Amasino RM (1995) Inhibition of leaf senescence by autoregulated production of cytokinin. Science 270: 1986-1988

Garbarino JE and Belknap WR (1994) Isolation of a ubiquitin-ribosomal protein gene (ubi3) from potato and expression of its promoter in transgenic plants. Plant Molec. Biol. 24: 119-127

Gartner J and NagI W (1980) Acid phosphatase activity in plastids (plastolysomes) of senescing embryo-suspensor cells. Planta 149: 341-349

Genschik P, Durr A and Fleck J (1994) Differential expression of several E2-type ubiquitin carrier protein genes at different developmental stages in Arabidopsis thaliana and Nicotiana sylvestris. Mol. Gen. Genet. 244: 548-556
Gilchrist D (1997) Mycotoxins reveal connections between plants and animals in apoptosis and ceramide signaling. Cell Death Differ. 4:689-698

Goldberg RB, Beals TP and Sanders PM (1993) Anther development: basic principles and practical applications. Plant Cell 5: 1217-1229

Goren R, Huberman M and Zamski E (1984) Anatomical aspects of citrus abscissioneffects of ethylene on leaf and fruit explants. In Y. Fuchs and E. Chalutz, eds, Ethylene. Biochemical, Physiological and Applied Aspects, Martinus Nijhoff, Boston, 241-254

GrantS, Beate Hand Saedler H(1994) Developmental differences between male and female flowers in the dioecious plant Silene Latifolia. Plant J. 6: 471-480

Greenberg JT (1996) Programmed cell death: a way of life for plants. Proc. Natl. Acad. Sci. USA 93: 12094 - 12097

Groover A, DeWitt N, Heidel A and Jones A (1997) Programmed cell death of plant tracheary elements differentiating in vitro. Protoplasma 196: 197-211

Haas AL, Baboshina O, Williams B and Schwartz LM (1995) Coordinated induction of the ubiquitin conjugation pathway accompanies the developmentally programmed death of insect skeletal muscle. J. Biol. Chem. 270: 9407-9412

Hansen DJ, Bellman SK and Sacher RM (1976) Gibberellic acid-controllled sex expression of corn tassels. Crop Sci. 16: $371-374$

Hadfield KA and Bennett AB (1997) Programmed senescence of plant organs. Cell Death Differ. 4: 662-670

He C, Drew MC and Morgan PW (1994) Induction of enzymes associated with lysigenous aerenchyma formation in roots of Zea mays during hypoxia or nitrogen starvation. Plant Physiol. 105: 861-865

He C, Morgan PW and Drew MC (1996) Transduction of an ethylene signal is required for cell death and lysis in the root cortex of maize during aerenchyma formation induced by hypoxia. Plant Physiol. 112: 463-472

Hengartner MO, Ellis RE and Horvitz HR (1992) Caenorhabditis elegans gene ced-9 protects cells from programmed cell death. Nature 356: 494-499

Hensel LL, Grbic V, Baumgarten DA and Bleecker AB (1993) Developmental and age-related processes that influence the longevity and senescence of photosynthetic tissues in Arabidopsis. Plant Cell 5: 553-564

Herman EM (1994) Multiple origins of intravacuolar protein accumulation of plant cells. Adv. Struc. Biol. 3: 243-283

Herrero M and Dickinson HG (1981) Pollen tube development in Petunia hybrida following compatible and incompatible intraspecific matings. J. Cell Sci. 47: $365-383$

Hochstrasser M (1995) Ubiquitin, proteasomes, and the regulation of intracellular protein degradation. Curr. Opin. Cell. Biol. 7: 215-223

Huang BQ, Pierson ES, Russell SD, Tiezzi A and Cresti M (1992) Video microscopic observations of living, isolated embryo sacs of Nicotiana and their component cells. Sex. Plant Reprod. 5: 156-162

Huang GQ and Russell SD (1994) Fertilization in Nicotiana tabacum: cytoskeletal modifications in the embryo sac during synergid degeneration. Planta 194: 200 214

Huberman M, Pressman E and Jaffe MJ (1993) Pith autolysis in plants: IV. The activity of polygalacturonase and cellulase during drought stress induced pith autolysis. Plant Cell Physiol. 34: 795-801

Iwahori S, Tominaga S and Higuchi S (1990) Retardation of abscission of citrus leaf and fruitlet explants by brassinolide. Plant Growth Reg. 9: 119-125

Jensen WA, Schulz P and Ashton ME (1977) An ultrastructural study of early endosperm development and synergid changes in unfertilized cotton ovules. Planta 133: 179-189

Jones AM and Dangl JL (1996) Logjam at the styx: programmed cell death in plants. Trends Plant Sci. 1: 1360-1385

Jones RL and Jacobsen JV (1991) Regulation of synthesis and transport of proteins in cereal aleurone. Int. Rev. Cytol. 126: 49-88

Jones ML, Larsen PB and Woodson WR (1995) Ethylene-regulated expression of a carnation cysteine proteinase during flower petal senescence. Plant Mol. Biol. 28: $505-512$

Kalaitzis P, KoehlerSMand TuckerML (1995) Cloning of a tomato polygalacturonase expressed in abscission zones. Plant Mol. Biol. 28: 647-656

Kawase M (1981) Anatomical and morphological adaptation of plants to waterlogging. HortSci. 16: 30-34

Kawase M (1979) Role of cellulase in aerenchyma development in sunflower. Amer. J. Bot. 66: $183-190$

Kawase M and Whitmoyer RE (1980) Aerenchyma development in waterlogged plants. Amer. J. Bot. 67: 18-22 
Kelly MO and Davies PJ (1988) The control of whole plant senescence. CRC Crit. Rev. Plant Sci. 7: 139-173

Kerr JFR and Harmon BV (1991) Definition and incidence of apoptosis: an historical perspective. In L.D. Tomei and F.O. Cope, eds. Curr. Comm. Cell Molec. Biol. 3. Cold Spring Harbor Press, 5-29

Kohlenbach HW and Schmidt B (1975) Cytodifferenzierung in form einer direkten umwandlung isolierter mesophyllzellen zu tracheiden. Z. Pflanzenphysiol. 75: 369-374

Koller AL and Rost TL (1988) Leaf anatomy in Sansevieiria (Agavaceae). Amer. J. Bot. 75: 615-633

Koltunow AM, Truettner J, Cox KH, Wallroth M and Goldberg RB (1990) Different temporal and spacial gene expression patterns occur during anther development. Plant Cell 2: 1201-1224

Kumar S and Lavin MF (1996) The ICE family of cysteine proteases as effectors of cell death. Cell Death Differ. 3: 255-267

Kuo A, Cappelluti S, Cervantes-Cervantes M, Rodriguez M and Bush DS (1996) Okadaic acid, a protein phosphatase inhibitor, blocks calcium changes, gene expression, and cell death induced by gibberellin in wheat aleurone cells. Plant Cell 8: 259-269

Lepiniec L, Babiychuk E, Kushnir S, Van Montagu M and Inez D (1995) Characterization of an Arabidopsis thaliana cDNA homologue to animal poly(ADP-ribose) polymerase. FEBS Lett. 364: 103-108

Lev-Yadun S (1994) Induction of sclereid differentiation in the pith of Arabidopsis thaliana (L.) Heynh. J. Exp. Bot. 45: 1845-1849

Li D, Blakey CA, Dewald C and Dellaporta SL (1997) Evidence for a common sex determination mechanism for pistil abortion in maize and its wild relative Tripsacum. Proc. Natl. Acad. Sci. USA in press

Li YQ, Southworth D, Linskens HF, Mulcahy DL and Cresti M (1995) Localization of ubiquitin in anthers and pistils of Nicotiana. Sex Plant Reprod. 8: 123-128

Liu X-Q and Jagendorf AT (1986) Neutral peptidases in the stroma of pea chloroplasts. Plant Physiol. 81: 603-608

Lohman KN, Gan S, John MC and Amasino RM (1994) Molecular analysis of natural leaf senescence in Arabidopsis thaliana. Physiol. Plant. 92: 322-328

Lu P, Gladish D and Rost TL (1991) Temperature-induced cavities and specialized cells in the vascular cylinder of pea roots. Amer. J. Bot. 78: 729-739

Makrides SC and Goldthwaite J (1981) Biochemical changes during bean leaf growth, maturity and senescence. Contents of DNA, polyribosomes, ribosomal RNA, protein and chlorophyll. J. Exp. Bot. 32: 725-735

MalekL, Bogorad L, Ayers A and Goldberg AL (1984) Newly synthesized proteins are degraded by ATP-stimulated processes in isolated pea chloroplasts. FEBS Lett. 166: $253-255$

Martin C and Thimann KV (1972) The role of protein synthesis in the senescence of leaves. I. The formation of protease. Plant Physiol. 49: 64-71

Martin SJ (1993) Apoptosis: suicide, execution or murder. Trends Cell Biol. 3: 141 144

Matile P and Winkenbach F (1971) Function of lysosomes and lysosomal enzymes in the senescing corolla of the morning glory (Ipomoea purpurea). J. Exp. Bot. 22 $959-771$

McClure BA, Gray JE, Anderson MA and Clark AE (1990) Self-incompatibility in Nicotiana alata involves degradation of pollen rRNA. Nature 347: 757-760

McConkey DJ and Orrenius S (1995) Calcium and cyclosporin A in the regulation of apoptosis. In G. Kroemer and C. Martinez-A., eds, Apoptosis in Immunology, Springer-Verlag, New York, 95-105

McCubbin AG, Chung Y and Kao T (1997) A mutant S3 RNase of Petunia inflata lacking RNase activity has an allele-specific dominant negative effect on selfincompatibility interactions. Plant Cell 9: 85-95

McCully ME (1989) Cell separation: a developmental feature of root caps which may be of fundamental significance. In D.J. Osborne and M.B. Jackson, eds, Cell Separation in Plants, Springer-Verlag, New York, 241-252

McPherson DC (1939) Cortical air spaces in the roots of Zea mays L. New Phytol. 38 : 190-202

Melville R and Wrigley FA (1968) Fenestration in the leaves of Monstera and its bearing on the morphogenesis and colour patterns of leaves. Bot. J. Linn. Soc. 62: $1-16$

Miller BL and Huffaker RC (1982) Hydrolysis of ribulose-1,5-bisphosphate carboylase by endoproteinases from senescing barley leaves. Plant Physiol. 69: $58-62$
Minami A and Fukuda $\mathrm{H}$ (1995) Transient and specific expression of a cysteine endoproteinase associated with autolysis during differentiation of Zinnia mesophyll cells in tracheary elements. Plant Cell Physiol. 36: 1599-1606

Mittler R, Shulaev V and Lam E (1995) Coordinated activation of programmed cell death and defense mechanisms in transgenic tobacco plants expressing a bacterial proton pump. Plant Cell 7: 29-42

Morel J-B and Dangl JL (1997) The hypersensitive response and the induction of cell death in plants. Cell Death Differ. 4:671-683

Morgan PW, Chuan-Jin H, De Greef JA and De Proft MP (1990) Does water stress promote ethylene synthesis by intact plants? Plant Physiol. 94: 1616-1624

Nagl W (1976) Ultrastructural and developmental aspects of autolysis in embryosuspensors. Ber. Deutsch. Bot. Ges. Bd. 89: 301-311

Nagl W (1977) Plastolysomes - plastids involved in the autolysis of the embryosuspensor in Phaseolus. Z. Pflanezenphysiol. 85: 45-51

Nasrallah JB, Stein JC, Kandasamy MK and Nasrallah ME (1994) Signaling the arrest of pollen tube development in self-incompatible plants. Science 266: $1505-$ 1508

Newbigin E, Anderson MA and Clarke AE (1993) Gametophytic self-incompatibility systems. Plant Cell 5: 1315-1324

Niki T, Gladish DK, Lu P and Rost TL (1995) Cellular changes precede cavity formation in the vascular cylinders of pea roots (Pisum Sativum L. Cv. Alaska). Int. J. Plant Sci. 156: 290-302

Nooden LD (1988) The phenomena of senescence and aging. In L.D. Nooden and A.C. Leopold, eds, Senescence and aging in plants, Academic Press, New York, $1-50$

Okita TW and Rogers JC (1996) Compartmentation of proteins in the endomembrane system of plant cells. Annu. Rev. Plant Physiol. Plant. Mol. Biol. 47: 327-350

Oparka KJ, Johnson RPC and Bowen ID (1981) Sites of acid phosphatase in the differentiating root protophloem of Nymphoides peltata (S.G. Gmel.) O. Kuntze. Support for the role of stacked ER in sieve-element autolysis. Plant Cell Environ. 4: $27-35$

Ramina A, Rascio N and Masia A (1989) The abscission process in peach: structural, biochemical and hormonal aspects. InD.J. Osborne and M.B. Jackson, eds, Cell Separation in Plants, Springer-Verlag, New York, 233-238

Reger BJ, Chaubal R and Pressey R (1992) Chemotropic responses by pearl millet pollen tubes. Sex. Plant. Repro. 5: 47-56

Reid JS and Meier H (1972) The function of the aleurone layer during galactomannan mobilization in germinating seeds of fenugreek (Trigonella foenum-graecumL.), crimson clover (Trifolium incarnatum L.) and lucerne (Medicago satavia L.): a correlative biochemical and ultrastructural study. Planta 106: 44-60

Rubin LL, Gatchalian CL, Rimon G and Brooks SF (1994) The molecularmechanisms of neuronal apoptosis. Curr. Opin. Neurobiol. 4: 696-702

Russel SD and Dumas C (1992) Double fertilization. Int. Rev. Cytol. 140: 357-388

Ryerson DE and Heath MC (1996) Cleavage of nuclear DNA into oligonucleosomal fragments during cell death induced by fungal infection or by abiotic treatments. Plant Cell 8: 393-402

Savidge RA (1983) The role of plant hormones in higher plant cellular differentiation. II. Experiments with the vascular cambium, and sclereid and tracheid differentiation in the pine, Pinus contorta. Histochem. J. 15: 447-466

SchobertC, Grobmann P, Gottschalk M, KomorE, Pecsvaradi A and Nieden U (1995) Sieve-tube exudate from Ricinus communis $\mathrm{L}$. seedlings contains ubiquitin and chaperones. Planta 196: 205-210

Schwartz BW, Vernon DM and Meinke DW (1997) Development of the suspensor, differentiation, communication, and programmed cell death during plant embryogenesis. In B.A. Larkins and I.K. Vasil, eds, Molecular Biology of Plant Seed Development, Kluwer, in press.

Schwartz LM (1992) Insect muscle as a model for programmed cell death. J. Neurobiol. 23: 1312-1326

Sexton R, Durbin ML, Lewis LN and Thomson WW (1980) Use of cellulase antibodies to study leaf abscission. Nature 283: 873-874

Sexton R and Roberts JA (1982) Cell biology of abscission. Annu. Rev. Plant Physiol. 33: $133-162$

Shanklin J, DeWitt ND and Flanagan JM (1995) The stroma of higher plant plastids contain ClpP and ClpC, functional homologs of Escherichia coli ClpP and ClpAI: an archetypal two-component ATP-dependent protease. Plant Cell 7: 17131722 
Singh MB, Bhalla PL and Malik CP (1980) Activity of some hydrolytic enzymes in autolysis of the embryo suspensor in Trapaeolum majus L. Ann. Bot. 45: 523527

Sjolund R (1997) Sieve element differentiation. Plant Cell 9: 1137-1146

Smart CM (1994) Gene expression during leaf senescence. New Phytol. 126: 419 448

Smart CM, Hosken SE, Thomas H, Greaves JA, Blair BG and WS (1995) The timing of maize leaf senescence and characterisation of senescence-related cDNAs. Physiol. Plant 93: 673-682

Smith MT, Saks Y and Van Staden J (1992) Ultrastructural changes in the petals of senescing flowers of Dianthus caryophyllus L. Ann. Bot. 69: 277-285

Staswick PE (1994) Storage proteins of vegetative tissues. Annu. Rev. Plant Physiol. Plant Molec. Biol. 45: 303-322

Sugimoto A, Hozak RR, Nakashima T, Nishimoto T and Rothman JH (1995) dad-1, an endogenous programmed cell death supressor in Caenorhabiditis elegans and vertebrates. EMBO J. 14: 4434-4441

Sumner MJ (1992) Embryology of Brassica campestris: the entrance and discharge of the pollen tube in the synergid and the formation of the zygote. Can. J. Bot. 70 $1577-1590$

Taylor CB, Bariola PA, DelCardayre SB, Raines RT and Green PJ (1993) RNS2: A senescence-associated RNase of Arabidopsis that diverged from the S-RNases before speciation. Proc. Natl. Acad. Sci. USA 90: 5118-5122

Taylor JE, Tucker GA, Lasslett Y, Smith CJS, Arnold CM, Watson CF, Achuch W, Grierson D and Roberts JA (1990) Polygalacturonase expression during leaf abscission of normal and transgenic tomato plants. Planta 183: 133-138

Tewari M, Quan LT, O'Rourke K, Desnoyers S, Zeng Z, Beidler DR, Poirier GG Salvesen GS and Dixit VM (1995) Yama/CPP32 $\beta$, a mammalian homolog of CED-3, is a CrmA-inhibitable protease that cleaves the death substrate poly(ADP-ribose) polymerase. Cell 81: 801-809

Thelen MP and Northcote DH (1989) Identification and purification of a nuclease from Zinnia elegans L.: a potential molecular marker for xylogenesis. Planta 179: $181-195$

Thomas CV, Esterly JR and Ruddat M (1977) Lightmicroscopical histochemistry of hydrolases in the root tip of lima beans, Phaseolus lunatus L., in relation to cell differentiation and wound regeneration. Protoplasma 91: 229-242

Thomas H and Stoddart JL (1980) Leaf senescence. Annu. Rev. Plant Physiol. 31: $83-111$

Thompson DS and Osborne DJ (1994) A role for stele in intertissue signaling in the initiation of abscission in bean leaves (Phaseolus vulgaris L.). Plant Physiol. 105: $341-347$

Thomson WW and Platt-Aloia KA (1987) Ultrastructure and senescence in plants. In W.W. Thomson, E.A., Nothnagel and R.C. Huffaker, eds, Plant Senescence: Its Biochemistry and Physiology, 10. American Society of Plant Physiologists, Rockville, 20-30
Tian H and Russell SC (1997) Distribution of calcium in fertilized and unfertilized ovules and embryo sacs of Nicotiana tabacum L. Planta in press

Valpuesta V, Lange NE, Guerreo C and Reid MS (1995) Up-regulation of a cysteine protease accompanies the ethylene-insensitive senescence of daylily (Hemerocallis) flowers. Plant Mol. Biol. 28: 575-582

Van Went J and Cresti M (1988) Pre-fertilization degeneration of both synergids in Brassica campestris ovules. Sex. Plant Reprod. 1: 208-216

Van Went JL and Willemse MTM (1984) Fertilization. InB.M. Johri, ed, Embryology of Angiosperms, Springer-Verlag, New York, 273-317

Vernon DM and Meinke DW (1994) Embryogenic transformation of the suspensor in twin, a polyembryonic mutant of Arabidopsis. Devel. Biol. 165: 566-573

Vigil EL (1970) Cytochemical and developmental changes in microbodies (glyoxysomes) and related organelles of castor bean endosperm. J. Cell Biol. 46: $435-454$

Wang H, Li J, Bostock RM and Gilchrist DG (1996) Apoptosis: a functional paradigm for programmed plant cell death induced by a host-selective phytotoxin and invoked during development. Plant Cell 8: 375-391

Wang Q, Monroe J and Sjolund RD (1995) Identification and characterization of a phloem-specific beta-amylase. Plant Physiol. 109: 743-750

Webster BD (1970) A morphogenetic study of leaf abscission in Phaseolus. Amer. J. Bot. 57: 443-451

Wilkinson KD (1988) Purification and structural properties of ubiquitin. In M. Rechsteiner, eds, Ubiquitin, Plenum Press, 5-38

Willemse MTM and Van Went JL (1984) The female gametophyte. In B.M. Johri, ed Embryology of angiosperms, Springer-Verlag, New York, 159-164

Williams AG and Whitham TG (1986) Premature Leaf Abscission: An induced plant defense against gall aphids. Ecology 67: 1619-1627

Wittenbach VA, Ackerson RC, Giaquinta RT and Hebert RR (1980) Changes in photosynthesis, ribulose bisphosphate carboxylase, proteolytic activity, and ultrastructure of soybean leaves during senescence. Crop Sci. 20: 225-231

Wittenbach VA, Lin W and Hebert RR (1982) Vacuolar localization of proteases and degradation of chloroplasts in mesophyll protoplasts from senescing primary wheat leaves. Plant Physiol. 69: 98-102

Wyllie AH (1980) Glucocorticoid-induced thymocyte apoptosis is associated with endogenous endonuclease activation. Nature 284: 555-556

Wyllie AH, Kerr JFR and Currie AR (1980) Cell death: the significance of apoptosis. Int. Rev. Cytol. 68: 251-305

Ye Z-H and Varner JE (1996) Induction of cysteine and serine proteinases during xylogenesis in Zinnia elegans. Plant Mol. Biol. 30: 1233-1246

Ye Z-H and Droste DL (1996) Isolation and characterization of cDNAs encoding xylogenesis-associated and wounding-induced ribonucleases in Zinnia elegans. Plant Mol. Biol. 30: 697-709

Yeung EC and Meinke DW (1993) Embryogenesis in angiosperms: development of the suspensor. Plant Cell 5: 1371-1381 